\title{
Fractionation of a Differentiated Mouse Leukemia Cell Line by Discontinuous Ficoll-Urografin Density Gradients
}

\author{
Hiroshi Sakagami*, Senwa Unten, Minoru Takeda, Ken Takeda and \\ Kunio Konno \\ Department of Biochemistry, School of Medicine, Showa University, 1-5-8 \\ Hatanodai, Shinagawa-ku, Tokyo 142, Japan
}

\begin{abstract}
The Ficoll-Urografin density gradient method was used to separate differentiated mouse myeloid cells (M1), and the properties of the fractionated cell populations were investigated.

During differentiation in vitro, M1 cells produced large adherent cells. These adherent cells showed an increased cell size and a decreased ratio of nucleus size to cell size (N/C ratio) in comparison with untreated M1 cells and nonadherent cells. With discontinuous Ficoll-Urografin density gradient centrifugation, adherent cells could be separated into subfractions with low $\mathrm{N} / \mathrm{C}$ ratios $(\mathrm{d}=1.033-1.054$, rich in macrophage-like cells); those with intermediate $\mathrm{N} / \mathrm{C}$ ratios $(\mathrm{d}=1.054-1.059$, rich in cells in the intermediate stages of differentiation); and those with high $\mathrm{N} / \mathrm{C}$ ratios $(\mathrm{d}=1.059-1.067$, rich in myeloblastic cells). Almost all the untreated M1 cells and nonadherent cells were banded in the high density region $(\mathrm{d}=1.059-1.067)$.

Both phagocytic and lysozymic activities were highest in the lowest density band. Elevated lysosomal enzyme activity in the highest density fraction of the fractionated cells indicates that these cells may differ from M1 cells in their biological activity.
\end{abstract}

The mouse myeloid leukemia cell line (M1), established from SL strain mice by Ichikawa (11), has been used as a model system to study cell differentiation (9). Ml cells are known to differentiate into granulocytes and macrophages on treatment with various inducers that include conditioned media from various cell cultures $(1,9,20)$, ascitic fluid of mice and rats bearing various tumors (10), and glucocorticoid hormones $(5,17)$. Differentiated M1 cells acquire phagocytic, locomotive and lysosomal enzyme activities (19) and show alterations in the components of their cell surface membranes $(17,18,21)$. The inverse relationship between leukemogenicity and the in vivo inducibility of cell differentiation $(6,8)$ has proved the chemotherapeutic usefulness of this system. Differentiated M1 cells, however, have been placed in numerous classifications that include myeloblastic cells, mature macrophages and granulocytes, and cells in intermediate stages. This heterogeneity has made it difficult to determine the relationships between cell type and differentiation-associated properties. To solve this problem, we tried a separation method that used Ficoll-Urografin density gradient centrifugation. This technique enabled us to fractionate differentiated cells by cell size and/or the ratio of nucleus size to cell size (N/C ratio). 


\section{MATERIALS AND METHODS}

Cell line and cell culture. M1 cells (clone T22, donated by Dr. M. Hozumi, Saitama Cancer Center Research Institute) were cultured in suspension in Eagle's minimal essential medium (MEM) which contained twice the normal concentrations of amino acids and vitamins, and which was supplemented with $10 \%$ heat-inactivated calf serum. Dexamethasone sodium phosphate (Orgadrone) (Sankyo, K.K.) was dissolved in phosphate buffered saline without calcium and magnesium (PBS( - )) then added to the medium.

Collection of adherent cells. Supernatant cells from hormone-treated cultures were pooled, and the loosely adherent cells were collected by gentle rinsing three times with pre-warmed growth medium $\left(37^{\circ} \mathrm{C}\right)$. These cells were combined and designated nonadherent cells. Cells that adhered after rinsing with the growth medium were designated adherent cells and were collected by pipetting them with cold PBS $(-)\left(0^{\circ} \mathrm{C}\right)$.

Fractionation by discontinuous Ficoll-Urografin density gradient centrifugation. Cells $\left(1 \times 10^{7}\right)$ were washed once with PBS( -$)$ and resuspended in $0.5 \mathrm{ml}$ of PBS $(-)$. Cells then were mixed with $0.5 \mathrm{ml}$ of $2.43 \%$ Ficoll solution. The components of the two stock solutions used to prepare the density gradients and the method of gradient formation are described in Table 1. The cell suspensions ( $1 \mathrm{ml}$ ) were layered gently on top of Ficoll-Urografin gradients composed of $1.4 \mathrm{ml}$ each of $2.43 \%(\mathrm{~d}=1.054), 3.0 \%(\mathrm{~d}=1.056), 4.0 \%(\mathrm{~d}=1.059)$, $5.0 \%(\mathrm{~d}=1.061), 6.0 \%(\mathrm{~d}=1.064)$ and $7.0 \%$ Ficoll solution $(\mathrm{d}=1.067)$, then they were centrifuged at 2,400 g for $15 \mathrm{~min}$ (Tomy, CD-50SN) in a cold room $\left(9^{\circ} \mathrm{C}\right)$.

Assay of the properties of differentiated cells. For the assay of phagocytic activity, cells were incubated for $4 \mathrm{~h}$ with a suspension of polystyrene latex particles $(2 \mu \mathrm{l} / \mathrm{ml}$ serum-free medium, average diameter $0.81 \mu \mathrm{m}$, Difco Lab. Co.). After incubation, the number of latex particles phagocytized per cell was determined in cell smears (at least 200 cells) (12). Lysozyme activity was assayed as described previously (7). The lysoplate composition was modified as follows: $1 \%(\mathrm{w} / \mathrm{v})$ Difco agar, $0.5 \%(\mathrm{w} / \mathrm{v})$ heat-killed Micrococcus Lysodeikticus (Sigma), $50 \mathrm{mM} \mathrm{NaCl}$ and $67 \mathrm{mM}$ sodium phosphate, $\mathrm{pH}$ 5.9. After the plates had been incubated for $24 \mathrm{~h}$ at $37^{\circ} \mathrm{C}$, the diameters of the cleared zones on the lysoplate were measured. One unit of activity was defined as the amount equivalent to $1 \mu \mathrm{g}$ of egg white lysozyme (Seikagaku Kogyo Co.) under the same conditions.

TABLE 1. Preparation OF DENSITy GRAdiENTS

\begin{tabular}{lcc}
\hline & High density & Low density \\
\hline Ficoll (MW 400,000, Pharmacia Fine Chem.) & $7.0 \mathrm{~g}$ & $2.43 \mathrm{~g}$ \\
Urografin $(76 \%)$ (Schering AG)) & $12.2 \mathrm{ml}$ & $12.0 \mathrm{ml}$ \\
$0.175 \mathrm{M}$ Tris- $\mathrm{HCl}\left(\mathrm{pH} 7.4\right.$ at $\left.4^{\circ} \mathrm{C}\right)$ & $11.8 \mathrm{ml}$ & $11.6 \mathrm{ml}$ \\
PBS(-) & $12.0 \mathrm{ml}$ & $17.6 \mathrm{ml}$ \\
Distilled water & $61.0 \mathrm{ml}$ & $58.0 \mathrm{ml}$ \\
Total volume & $100.0 \mathrm{ml}$ & $100.0 \mathrm{ml}$ \\
Density at $4^{\circ} \mathrm{C}$ & $1.067 \mathrm{~g} / \mathrm{ml}$ & $1.054 \mathrm{~g} / \mathrm{ml}$ \\
pH at $4^{\circ} \mathrm{C}$ & 7.5 & 7.5 \\
Osmolarity & $290 \mathrm{mOsm}$ & $290 \mathrm{mOsm}$
\end{tabular}

Osmolarity measured by the lowering of the relative vapor pressure. Discontinuous density gradients obtained by successive layering of solutions with decreasing densities in $13 \mathrm{ml}$ siliconized test tubes ( $\phi 13 \mathrm{~mm}$, length $103 \mathrm{~mm}$ ). Solutions with the desired density were mixed from stock solutions according to following equation: required density $=a(1.067)+(1-a) 1.054$. 
Cell sizing. Cell size and nucleus size were determined by microscopic examination of cell smears treated with May-Grünwald-Giemsa stain and were expressed as the length of the longest axis of each cell and of its nucleus. Cellular volumes were measured in a Coulter ZBI Channelyzer equipped with a $70 \mu \mathrm{m}$ diameter aperture tube (Nikkaki, K.K.). Polystyrene beads $20.2 \mu \mathrm{m}$ in diameter were used to calibrate the instrument.

\section{RESULTS AND DISCUSSION}

Adherent cell accumulation during in vitro differentiation. M1 cells were induced to differentiate by treatment with $10^{-6} \mathrm{M}$ dexamethasnoe sodium phosphate (4). During in vitro differentiation, the doubling time of M1 cells increased from $21 \mathrm{~h}$ to $34 \mathrm{~h}$ (Fig. 1a), and M1 cells acquired the property of adhesion to glass surfaces (Fig. 1b). The percent of adherent cells increased until it reached a peak (about $70 \%$ ) at $30-50 \mathrm{~h}$ after treatment, after which a slight decrease occurred (Fig. 1b). The background level of adhesion seen in untreated cultures may be due to spontaneously changing M1 cell clones.

Fig. 2 shows that the adherent cells from treated cultures (b) are significantly larger than the control M1 cells (a) and nonadherent cells. The proportionate increase in cell size which exceeded that of nucleus size caused a slight decrease in the $\mathrm{N} / \mathrm{C}$ ratio of the adherent cells $(0.93 \pm 0.07(n=50)$ (control cells) vs $0.83 \pm 0.07(n=50)$ (adherent cells)). The typical morphology of these cells is shown in Fig. 3. Untreated M1 cells (a) and nonadherent cells (b), had large round nuclei and little cytoplasm whereas the adherent cells had small nuclei and enlarged cytoplasms (c). With a Coulter Channelyzer (Nikkaki, K.K.), we found that the mean cell volume of the adherent cells $\left(747 \mu \mathrm{m}^{3}\right)$ was significantly larger than that of M1 cells $\left(575 \mu \mathrm{m}^{3}\right)$ and nonadherent cells $\left(525 \mu \mathrm{m}^{3}\right)$.

Table 2 shows that before fractionation, the adherent cells consisted of nearly equal portions of three cell types: macrophage-like cells $(27 \%)$, myeloblastic cells $(32 \%)$
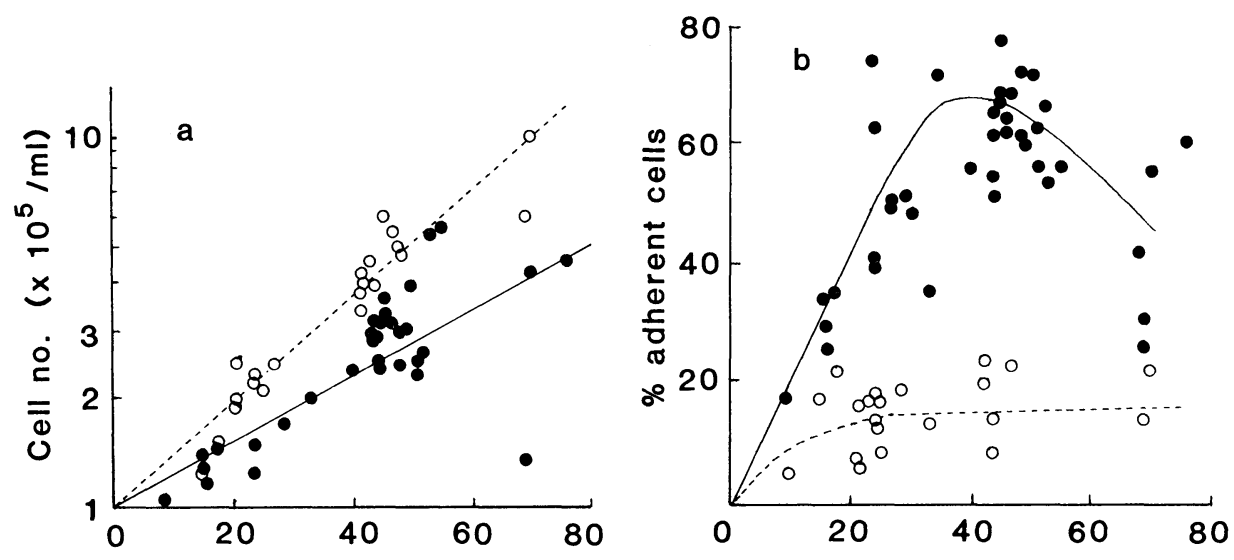

\section{Incubation time $(h)$}

Fig. 1. Adherent cell accumulation during in vitro differentiation. (a) Growth curve as a function of incubation time of M1 cells incubated without ( $\bigcirc-\cdots-\cdots)$ or with $10^{-6} \mathrm{M}$ dexamethasone (๑(b) Percent of adherent cells in the total number. 


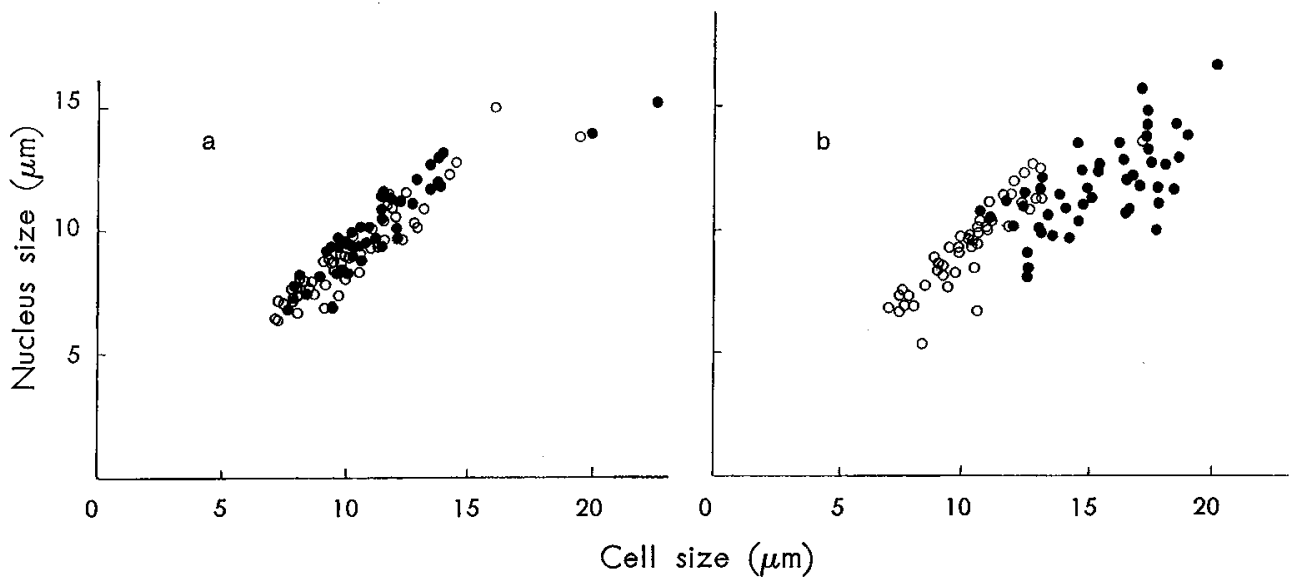

Fig. 2. Relation between changes in the size of the cell and nucleus induced by dexamethasone. $\mathrm{M} 1$ cells were incubated for $47 \mathrm{~h}$ without (a) or with $10^{-6} \mathrm{M}$ dexamethasone (b). Sizes of the cells and nuclei of adherent ( $)$ and nonadherent cells $(O)$ were determined as described in MATERIALS AND METHODS.

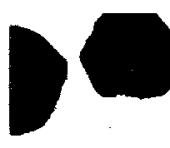

a
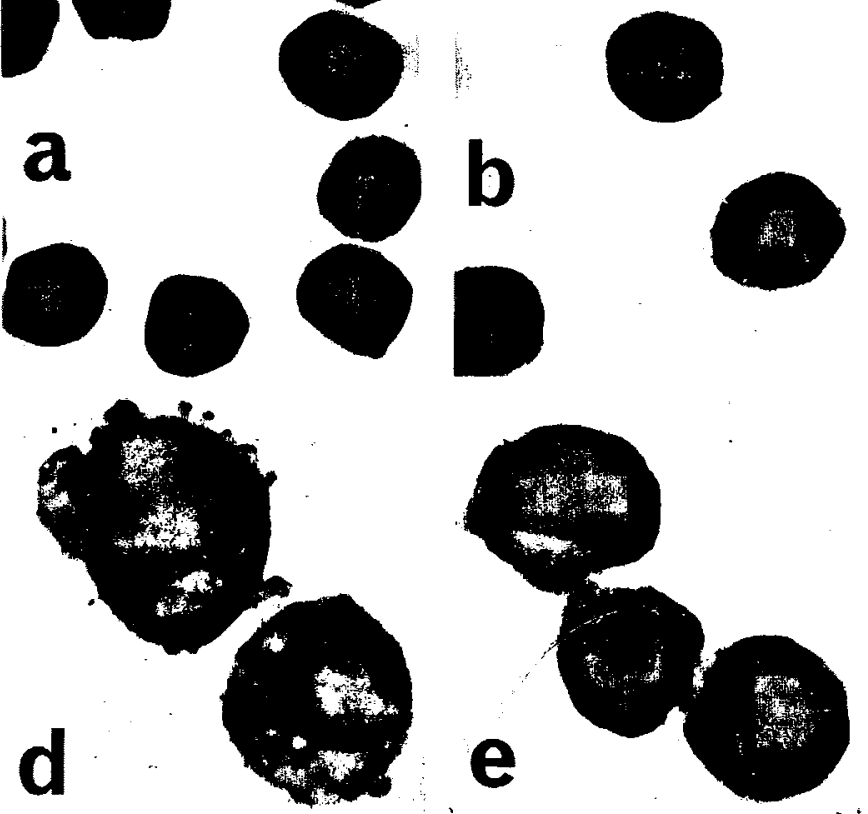
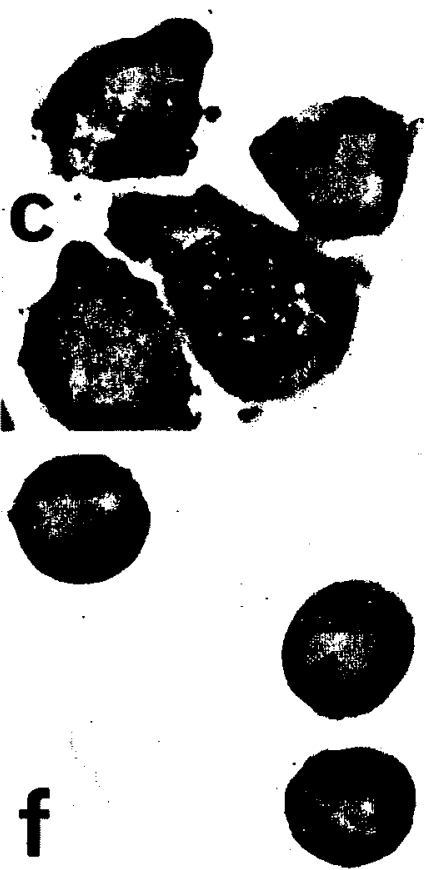

Fig. 3. Morphology of differentiated M1 cells. (a) Untreated M1 cells. (b-f) M1 cells treated for $55 \mathrm{~h}$ with $10^{-6} \mathrm{M}$ dexamethasone. (b) Nonadherent cells. (c) Adherent cells. Adherent cells were fractionated into the following three subfractions on Ficoll-Urografin density gradients : (d) cells distributed at the density of 1.033-1.054 $\mathrm{g} / \mathrm{ml}$ (Group I), (e) cells at 1.054-1.059 g/ml (Group II) and (f) cells at $1.059-1.067 \mathrm{~g} / \mathrm{ml}$ (Group III). May-Grünwald-Giemsa. $\quad \times 1,000$ 
TABLE 2. MORPHOLOGICAL CHANGES INDUCED IN FRACTIONATED M1 (T22) CELLS BY DEXAMETHASONE

\begin{tabular}{|c|c|c|c|c|c|c|}
\hline & \multirow{2}{*}{$\begin{array}{l}\text { Ficoll } \\
\text { conc. } \\
(\%)\end{array}$} & \multirow{2}{*}{$\begin{array}{l}\text { Density } \\
\text { at } 4^{\circ} \mathrm{C} \\
(\mathrm{g} / \mathrm{ml})\end{array}$} & \multicolumn{4}{|c|}{$\%$ cells } \\
\hline & & & $\begin{array}{c}\text { Mature } \\
\text { macrophages }\end{array}$ & $\begin{array}{c}\text { Mature } \\
\text { granulocytes }\end{array}$ & $\begin{array}{l}\text { Intermediate } \\
\text { stage cells }\end{array}$ & $\begin{array}{l}\text { Myeloblastic } \\
\text { cells }\end{array}$ \\
\hline \multicolumn{7}{|l|}{ Adherent cells } \\
\hline \multirow[t]{6}{*}{ Exp I. } & $1.2-2.4$ & $1.033-1.054$ & 51 & 2 & 38 & 9 \\
\hline & $2.4-3.0$ & $1.054-1.056$ & 32 & 4 & 44 & 20 \\
\hline & $3.0-4.0$ & $1.056-1.059$ & 29 & 2 & 53 & 16 \\
\hline & 4. $0-5.0$ & $1.059-1.061$ & 2 & 0 & 16 & 82 \\
\hline & $5.0-6.0$ & $1.061-1.064$ & 2 & 0 & 13 & 85 \\
\hline & $6.0-7.0$ & $1.064-1.067$ & 2 & 0 & 16 & 82 \\
\hline \multirow[t]{6}{*}{ Exp II. } & $1.2-2.4$ & $1.033-1.054$ & 72 & 0 & 23 & 5 \\
\hline & $2.4-3.0$ & $1.054-1.056$ & - & - & - & - \\
\hline & $3.0-4.0$ & $1.056-1.059$ & 36 & 3 & 47 & 14 \\
\hline & 4. $0-5.0$ & $1.059-1.061$ & 4 & 0 & 34 & 62 \\
\hline & $5.0-6.0$ & $1.061-1.064$ & 5 & 0 & 20 & 75 \\
\hline & $6.0-7.0$ & $1.064-1.067$ & 1 & 0 & 11 & 88 \\
\hline Adherent cells ${ }^{\mathrm{a}}$ & \multicolumn{2}{|c|}{ (not fractionated) } & 27 & 1 & 40 & 32 \\
\hline Nonadherent cells ${ }^{a}$ & \multicolumn{2}{|c|}{ (not fractionated) } & 1 & 1 & 17 & 81 \\
\hline Control M1 cells ${ }^{\mathrm{b}}$ & \multicolumn{2}{|c|}{ (not fractionated) } & 0 & 0 & 18 & 82 \\
\hline
\end{tabular}

M1 cells incubated with $10^{-6} \mathrm{M}$ dexamethasone for $55 \mathrm{~h}$ (Exp-1) or $76 \mathrm{~h}$ (Exp-II). Adherent cells were collected and fractionated by the Ficoll-Urografin density gradient method. Percentages of cells morphologically similar to granulocytes and macrophages were determined in smears treated with May-Grünwald-Giemsa stain (10).

a $\mathrm{M} 1$ cells incubated for $47 \mathrm{~h}$ with $10^{-6} \mathrm{M}$ dexamethasone.

b M1 cells incubated for $47 \mathrm{~h}$ without dexamethasone.

and cells in intermediate stages of differentiation (40\%). M1 cells and nonadherent cells were mainly myeloblastic $(81-82 \%)$. Negligible numbers of granulocytes were formed during in vitro differentiation (0-1\%).

Cell fractionation by Ficoll-Urografin density gradients. Since adherent cells still contained numerous cell types of different sizes, we had to fractionate these cell populations further. This was done with Ficoll-Urografin density gradients. Because of the importance of maintaining proper conditions during cell separation (15), the osmolarity and $\mathrm{pH}$ in the gradient solutions were adjusted to maintain constant physiological values (Table 1). Cells were fractionated by centrifugation at 2,400 $\mathrm{g}$ for $15 \mathrm{~min}$ in subsequent experiments, a condition found to be sufficient for M1 cells to migrate and equilibrate (data not shown). After fractionation, $60-80 \%$ of the initial cells were recovered and at least $95 \%$ of the recovered cells were viable as judged by trypan blue dye exclusion.

Density distribution profiles of adherent (a) and nonadherent cells (b) from treated cultures, and control M1 cells (c), which were fractionated by Ficoll-Urografin density gradients are shown in Fig. 4. Cells were separated by differences in cell size and $\mathrm{N} / \mathrm{C}$ ratios as well as by cell density, and the decrease in cell density was accompanied by an increase in cell size and a decrease in the $\mathrm{N} / \mathrm{C}$ ratio. Almost all the nonadherent cells (b) and M1 cells (c) were banded at the interfaces between $4 \%(\mathrm{~d}=1.059)$ and $5 \%$ Ficoll $(\mathrm{d}=1.061)$ and between $5 \%$ and $6 \%$ Ficoll $(\mathrm{d}=1.064)$. But, $37 \%$ of the adherent 


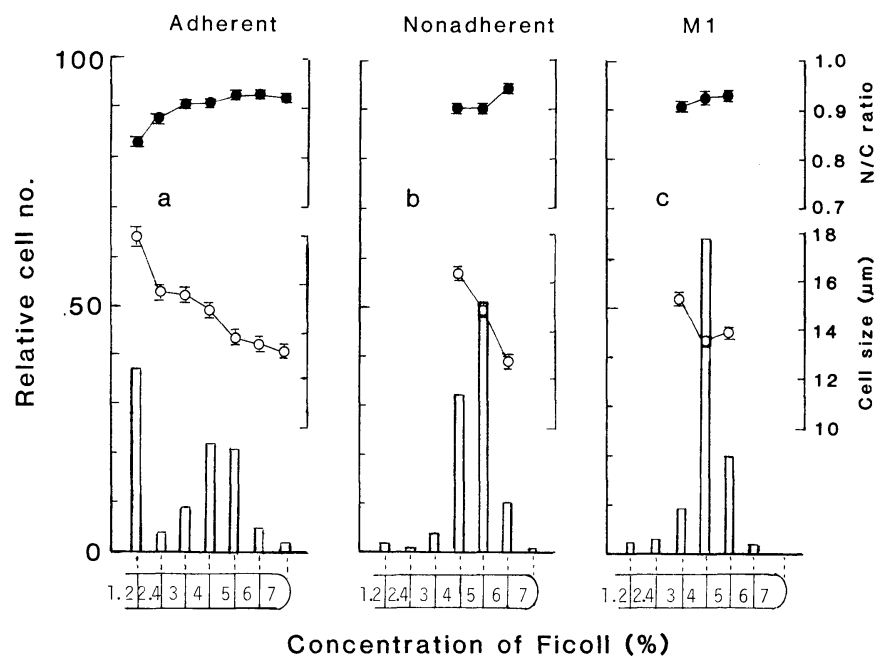

Fig. 4. Density distribution profiles of differentiated and control M1 cells. M1 cells treated with $10^{-6} \mathrm{M}$ dexamethasone for $55 \mathrm{~h}$. Adherent (a) and nonadherent cells (b) from treated cultures, and control M1 cells (c) were fractionated by Ficoll-Urografin density gradients as described in MATERIALS AND Methods. The bar represents the relative cell number distributed at each interface after fractionation. Cell size $(O)$ and the $\mathrm{N} / \mathrm{C}$ ratio $(\bullet)$ were determined as described in MATERIALS AND Methods, and are expressed as the mean \pm S.E. $(n=100)$.

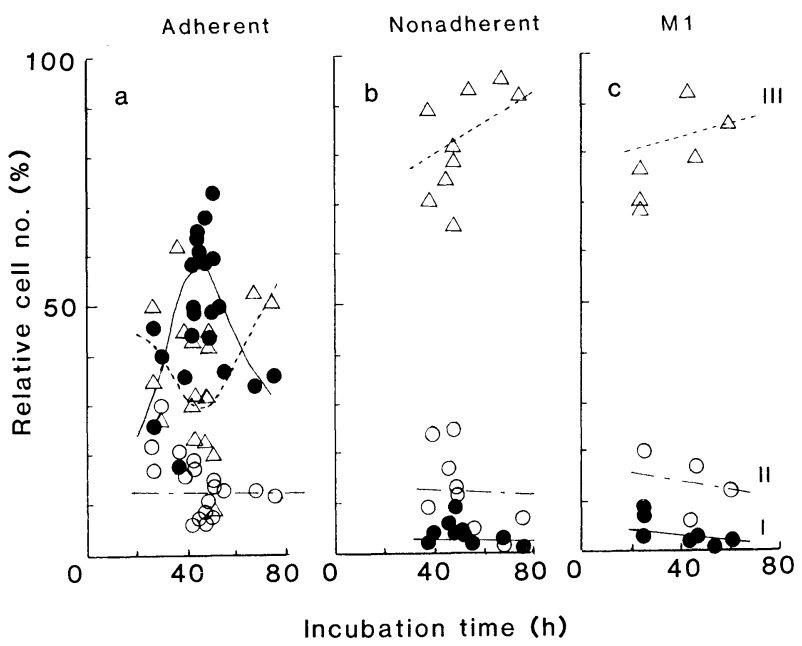

Fig. 5. Kinetics of distribution of cells in Groups I, II and III before (c) and after (a, b) dexamethasone treatment. M1 cells were treated with $10^{-6} \mathrm{M}$ dexamethasone for indicated times. Adherent (a) and nonadherent cells (b) from treated cultures, and control M1 cells (c) were fractionated as described in Fig. 4. Percentage of cell distribution at densities of 1.033-1.054 (Group I) (1.054-1.059 (Group II) ( $\bigcirc-\cdots-\bigcirc)$ and 1.059-1.067 (Group III) $(\triangle \cdots \cdots-\cdots)$ ). 
cells formed a new band at the interface between $1.2 \%(\mathrm{~d}=1.033)$ and $2.43 \%$ Ficoll $(\mathrm{d}=1.054)(\mathrm{a})$. These adherent cells with a large cell size and a small $\mathrm{N} / \mathrm{C}$ ratio (Fig. $4 a)$, and those fractions rich in macrophage-like cells (Table 2) characteristically separated into this 1.033-1.054 band (Fig. 3d).

Table 2 shows that the bands at the interfaces between $2.43 \%$ and $3.0 \%$ Ficoll and between $3.0 \%$ and $4.0 \%$ Ficoll consisted mainly of intermediate stage cells (Fig. 3e), and that those cells which banded at the interfaces between $4.0 \%$ and $5.0 \%$ Ficoll, between $5.0 \%$ and $6.0 \%$ Ficoll and between $6.0 \%$ and $7.0 \%$ Ficoll were mainly myeloblastic cells (Fig. 3f). Thus, the Ficoll-Urografin density gradients could divide the differentiated M1 cells roughly into the following three groups: (Group I) Mature macrophage-like cells $(\mathrm{d}=1.033-1.054)$, (Group II) intermediate stage cells $(\mathrm{d}=$ 1.054-1.059), and (Group III) myeloblastic cells $(\mathrm{d}=1.059-1.067)$.

The major portion of M1 cells before treatment with dexamethasone, consisted of Group III cells (c) (Fig. 5). After dexamethasone treatment, Group III cells predominated in the nonadherent cell fraction (b); Group I cells were found mainly in the adherent cell fraction (a). The percentage of Group II cells was about equal in all three samples (a, b, c). The presence of Group I cells peaked at $40-50 \mathrm{~h}$ after treatment (Fig. 5a), which coincided with the peak of maximum cell adherence (Fig. 1b).

Properties of fractionated cells. We next investigated differentiation-associated properties in the three distinct cell populations which had been separated by FicollUrografin density gradients. As the density of the separated adherent cells decreased, both the percentage of phagocytic cells and the number of latex particles phagocytized by a single cell increased $(15 \% \rightarrow 37 \% \rightarrow 91 \%$, and $0.6 \pm 0.1 \rightarrow 1.7 \pm 0.2 \rightarrow 7.5 \pm 0.4$, respectively) (Table 3 ). The phagocytic activity of Group III cells from adherent cell cultures was nearly identical with that of the nonadherent and control M1 cells.

Lysozyme activity, assayed under optimal conditions, also was correlated negatively with the density of separated adherent cells (Table 3 ). The nonadherent cells and the Group III cells from adherent cell cultures, however, unexpectedly had much greater

TABLE 3. INDUCTION OF DIFFERENTIATION-ASSOCIATED PROPERTIES IN FRACTIONATED M1 (T22) CELLS

\begin{tabular}{|c|c|c|c|c|c|c|c|c|c|c|}
\hline \multirow{3}{*}{ Cell type } & \multirow{3}{*}{$\begin{array}{c}\text { Density at } 4^{\circ} \mathrm{C} \\
(\mathrm{g} / \mathrm{ml})\end{array}$} & \multirow{3}{*}{$\begin{array}{c}\text { Lysozyme } \\
\text { activity } \\
\text { (unit/mg } \\
\text { protein) }\end{array}$} & \multicolumn{8}{|c|}{ Phagocytic activity( $\%$ cells $)$} \\
\hline & & & \multicolumn{8}{|c|}{ No. of latex particles phagocytized per cellc } \\
\hline & & & 0 & $1-5$ & $6-10$ & $11-15$ & $16-20$ & $21-25$ & $26-30$ & $31-35$ \\
\hline \multirow[t]{3}{*}{ Adherent cells ${ }^{\mathrm{a}}$} & $\begin{array}{l}1.033-1.054 \\
\text { (Group I) }\end{array}$ & $45.7 \pm 6.6^{b}$ & 9 & 41 & 25 & 15 & 6 & 2 & 1 & 1 \\
\hline & $\begin{array}{l}1.054-1.059 \\
\text { (Group II) }\end{array}$ & $43.0 \pm 7.8$ & 63 & 27 & 7 & 3 & 0 & 0 & 0 & 0 \\
\hline & $\begin{array}{l}\text { 1.059-1.067 } \\
\text { (Group III) }\end{array}$ & $26.0 \pm 7.6$ & 85 & 12 & 2 & 0 & 1 & 0 & 0 & 0 \\
\hline Nonadherent cells ${ }^{\mathrm{a}}$ & (not fractionated) & $16.7 \pm 5.0$ & 81 & 17 & 2 & 0 & 0 & 0 & 0 & 0 \\
\hline M1 cells & (not fractionated) & $3.2 \pm 0.6$ & 89 & 9 & 2 & 0 & 0 & 0 & 0 & 0 \\
\hline
\end{tabular}

${ }^{\text {a }} \mathrm{M} 1$ cells incubated with $10^{-6} \mathrm{M}$ dexamethasone for $48 \mathrm{~h}$. Adherent cells were collected and fractionated by the Ficoll-Urografin density gradient method.

b mean \pm S.E. from 3 independent experiments.

c determined from at least 200 viable cells in smears treated with May-Grünwald-Giemsa stain after fractionation on Ficoll-Urografin density gradients. 
lysozyme activity than the control M1 cells (Table 3), although all these cells had myeloblastic morphology (Table 2) and identical cell sizes and/or N/C ratios (Fig. 4). Acid-phosphatase and $\beta$-glucuronidase activities showed similar trends but at lower levels (data not shown).

There has been no report on the fractionation of differentiated M1 cells. We have succeeded in separating these cells into three distinct groups: Group I $(\mathrm{d}=1.033$ 1.054), Group II $(\mathrm{d}=1.054-1.059)$ and group III $(\mathrm{d}=1.059-1.067)$ (Table 2$)$. Many differentiation-associated properties which have been reported previously (i.e., changes in cell size and $\mathrm{N} / \mathrm{C}$ ratio (3), phagocytic or lysozymic activity (9, 19 etc.) were concentrated in the lightest fraction of adherent cells (Group I cells) in our study. The criteria we used for classifying Group I cells as macrophages were their adherence to a glass surface (Fig. 1b) $(16,17)$, their low density, small N/C ratio (Fig. 4) $(2,9$, $13)$, and their high phagocytic activity (Table 3$)(14,19)$.

Our study also revealed that nonadherent cells and Group III cells from adherent cell cultures with a cell size and/or N/C ratio identical with those of $\mathrm{M} 1$ cells, had much greater lysozyme (Table 3), acid-phosphatase and $\beta$-glucuronidase activities than the control M1 cells. Two-dimensional gel electrophoretic analysis of the total cellular proteins from these cells showed that dexamethasone differentiation induced increases in the amounts of several proteins (unpublished data). Conceivably both the nonadherent cells and the heaviest density fraction of adherent cells (Group III cells) from treated cultures may be belcng to a cell type that differs from that of untreated M1 cells, or these cells may be precursor cells destined for future differentiation into mature macrophages. The co-existence of steroid-resistant cells and steroid-sensitive cells (4) may reflect the heterogeneity of M1 cells.

Further analysis of these fractionated cells will be helpful in the determinations of the relative contributions of individual cell types to the overall function of the M1 line and the molecular mechanism of differentiation.

Acknowledgments. We thank Professor T. Suda, Drs M. Hozumi, J. Okabe, T. Kasukabe, Y. Makino, E. Hanada and E. Abe for their helpful discussions; Miss S. Ito for measuring the osmolarity; Dr. H. Mohri for measuring cell volumes; Dr. N. Nunoue for taking photographs of the control and differentiated Ml cells; and Dr. A. Simpson for reading the manuscript. This work was supported in part by a Grant-in-Aid for Cancer Research from the Ministry of Education, Science and Culture, Japan.

\section{REFERENCES}

1. Fibach, E., T. LANDAu and L. Sachs. Normal differentiation of myeloid leukemic cells induced by a differentiation-inducing protein. Nature New Biol. 237, 276-278, 1972

2. Fogelman, A.M., J. Serger, M. Нokom and P.A. Edwards. Separation of and cholesterol synthesis by human lymphocytes and monocytes. J. Lipid Res. 20, 379-388, 1979

3. Hirai, K., K. Nagata, M. Maeda and Y. Ichikawa. Changes in ultrastructures and enzyme activities during differentiation of myeloid leukemia cells to normal macrophages. Exp. Cell Res. 124, 269-283, 1979

4. Honma, Y., T. Kasukabe, J. OKabe and M. Hozumi. Glucocorticoid-induced differentiation of cultured mouse myeloid leukemia cells. Gann. 68, 241-246, 1977

5. Honma, Y., T. Kasukabe and M. Hozumi. Structure requirements and affinity of steroids to bind with receptor for induction of differentiation of cultured mouse myeloid leukemia cells. Gann. 68, 405-412, 1977

6. Honma, Y., T. Kasukabe and M. Hozumi. Relationship between leukemogenicity and in vivo 
inducibility of normal differentiation in mouse myeloid leukemia cells. J. Natl. Cancer Inst. 61, 837-841, 1978

7. Honma, Y., T. Kasukabe and M. Hozumi. Inhibition of differentiation of cultured mouse myeloid leukemia cells by nonsteroidal antiinflammatory agents and counteraction of the inhibition by Prostaglandin E. Cancer Res. 39, 2190-2194, 1979

8. Honma, Y., T. Kasukabe, J. Okabe and M. Hozumi. Prolongation of survival time of mice inoculated with myeloid leukemia cells by inducers of normal differentiation. Cancer Res. 39, 3167-3171, 1979

9. Hozumi, M., Y. Honma, M. Tomida, J. Okabe, T. Kasukabe, K. Sugiyama, M. Hayashi, K. TAKenaGa and Y. Yамамото. Induction of differentiation of myeloid leukemia cells with various chemicals. Acta. Haem. Jap. 42, 941-952, 1979

10. Hozumi, M., K. Takenaga, M. Tomida and J. OKabe. Role of leukocytes in ascites in the production of factor(s) stimulating differentiation of mouse myeloid leukemia cells. Gann. 68 , 643-652, 1977

11. Ichikawa, Y. Differentiation of a cell line of myeloid leukemia. J. Cell. Physiol. 74, 223-234, 1969

12. ICHIKAWA, Y. Further studies on the differentiation of a cell line of myeloid leukemia. J. Cell. Physiol. 76, 175-184, 1970

13. Loos, H., B. Block-Schut, R. van Doorn, R. Hoksbergen, A. Brutel de la Riviere and L. MeErhof. A method for the recognition and separation of human blood monocytes on density gradients. Blood. 48, 731-742, 1976

14. Loos, H., B. Block-Schut, B. Kipp, R. van Doorn and L. Meerhof. Size distribution, electronic recognition, and counting of human blood monocytes. Blood. 48, 743-753, 1976

15. Loos, J.A. and D. Roos. Ficoll-Isopaque gradients for the determination of density distributions of human blood lymphocytes and other reticulo-endothelial cells. Exp. Cell Res. 86, 333-341, 1974

16. Lotfm, J. and L. SAchs. Control of normal differentiation of myeloid leukemic cells. VI. Inhibition of cell multiplication and the formation of macrophages. J. Cell. Physiol. 85, 587-594, 1975

17. Lotem, J. and L. SACHS. Induction of specific changes in the surface membrane of myeloid leukemic cells by steroid hormones. Int. J. Cancer 15, 731-740, 1975

18. Lotem, J., I. Vlodavsky and L. SACHS. Regulation of cap formation by concanavalin A and the differentiation of myeloid leukemic cells. Relationship to free and anchored surface receptors. Exp. Cell Res. 101, 323-330, 1976

19. Nagata, K., E. Takahashi, M. Saito, J. Ono, M. Kuboyama and K. Ogasa. Differentiation of a cell line of mouse myeloid leukemia. I. Simultaneous induction of lysosomal enzyme activities and phagocytosis. Exp. Cell Res. 100, 322-328, 1976

20. SACHS, L. Control of normal cell differentiation and the phenotypic reversion of malignancy in myeloid leukaemia. Nature 274, 535-539, 1978

21. Sugryama, K., M. Tomida and M. Hozumi. Differentiation-associated changes in membrane proteins of mouse myeloid leukemia cells. Biochim. Biophys. Acta 587, 169-179, 1979 